\title{
Virus-Associated Demyelination in the Pathogenesis of Bell's Palsy
}

\author{
Hitoshi Honda and Akira TAKAHASHI
}

\begin{abstract}
We examined the cerebrospinal fluid findings, including the activity of the myelin-associated enzyme $2^{\prime}, 3^{\prime}$-cyclic nucleotide $3^{\prime}$-phosphohydrolase (CNP), and virus serology in patients with Bell's palsy. Eighty-nine of 164 patients showed hematological and/or serological evidence of an inflammatory reaction. Examinations of the CSF disclosed an elevated total protein level and pleocytosis in $33 \%$ and $10 \%$ of the 91 patients, respectively. The activity of CNP was significantly elevated in the patient group $(15.5 \pm 3.8 \mathrm{nmol} / \mathrm{h} / \mathrm{ml})$ as compared with the control $(13.2 \pm 1.3 \mathrm{nmol} / \mathrm{h} / \mathrm{ml})(\mathrm{p}<0.01)$, suggesting the presence of intrathecal myelin breakdown. Furthermore, there was an association between antibodies against herpes simplex virus (HSV) and elevated CNP activity. The inflammatory alterations and accompanying spinal fluid abnormalities, together with the high frequency of HSV antibodies suggest that HSV-associated demyelination may play a pathogenetic role in Bell's palsy.
\end{abstract}

(Internal Medicine 31: 1250-1256, 1992)

Key words: herpes simplex virus, cerebrospinal fluid, $2^{\prime}, 3^{\prime}$-cyclic nucleotide $3^{\prime}$-phosphohydrolase

\section{Introduction}

Idiopathic peripheral facial palsy (Bell's palsy) is a common neuropathy that results from an intrinsic lesion of the seventh cranial nerve. To date, many hypotheses have been presented to explain the etiology of this disorder $(1,2)$. However, since the prognosis of facial paralysis is generally good and postmortem studies are quite rare (3) it is difficult to establish the true pathologic nature of Bell's palsy. Even the site along the facial nerve of the lesion is still uncertain.

Since cases of Bell's palsy are often preceded by a mild infection (4) and patients may have an accompaning cerebrospinal fluid (CSF) pleocytosis $(5,6)$, some studies have attempted to correlate facial paralysis with viral infection. Viruses, including herpes simplex $(7,8)$, rubella (9), mumps (10) and Epstein-Barr virus (11), have been associated with Bell's palsy. Some studies have demonstrated that several human viruses can experimentally infect the facial nerve and geniculate ganglia (12), and that herpes simplex virus (HSV) can induce peripheral nerve demyelination in mice $(13,14)$. However, to date, only varicella-zoster virus (VZV) (15) and poliovirus (16) have been demonstrated as causative agents of facial nerve paralysis in humans.

In an attempt to evaluate the possible pathomechanism of virus-associated demyelination in the development of facial nerve paralysis, we examined the activity of the myelin-associated enzyme 2', $3^{\prime}$-cyclic nucleotide $3^{\prime}$ phosphohydrolase (CNP) (17) in the CSF and the virus serology in patients with Bell's palsy.

\section{Patients and Methods}

\section{Patients}

We examined 164 patients with acute 'idiopathic' peripheral facial palsy. Diagnosis of Bell's palsy was made according to Taverner's diagnostic criteria (1). This study included 75 male and 89 female patients, who ranged from one to 89 years of age (average age, 44.2 years); in 80 patients the palsy was right-sided. Nine patients $(5.5 \%)$ were experiencing a recurrence of the palsy, 15 patients $(9.1 \%)$ had hypertension, eight $(4.9 \%)$ were known diabetics, five $(3.0 \%)$ had chronic hepatitis, and one was pregnant. The majority of the patients had come to our clinic within seven days of the onset of facial paralysis. At the time of the first visit, peripheral blood was taken for routine laboratory tests, namely, erythrocyte sedimentation rate (ESR), white blood cell count, C-reactive protein (CRP), and cold hemagglutinin $(\mathrm{CH})$ titer. Blood samples from 76 healthy volunteers, 39 males and 37 females who ranged in age from 18 to

From the Department of Neurology, Nagoya University School of Medicine, Nagoya

Received for publication Junc 1, 1992; Accepted for publication September 11, 1992

Reprint requests should be addressed to Dr. Hitoshi Honda, the Department of Neurology, Nagoya University School of Medicine, 65, Tsurumaicho, Showa-ku, Nagoya 466, Japan 


\section{Demyelination in Bell's Palsy}

60 years (average 36.9 ), were used as reference samples for laboratory tests.

\section{Virus serology}

Serum samples were collected at the time of the first visit and 2-5 weeks later. Serum was tested for complement-fixing (CF) antibodies against HSV, VZV, mumps virus and Coxsackie A9 virus, and indirect immunofluorescence was carried out to detect IgG antibodies against the capsid antigens of Epstein-Barr virus (EBV). CF antibodies and the antibodies against EBV were considered to be positive at titers of greater than $1: 4$ and $1: 40$, respectively.

A recent infection with VZV was indicated by changes in antibody titers in five patients who showed no herpetic eruptions (zoster sine herpete) (18). We did not include these cases in the present study.

\section{Examination of cerebrospinal fluid (CSF)}

Samples of CSF were obtained from 91 patients within seven days of the onset of facial paralysis. Cell counts and glucose levels were determined, and total protein was assayed by the method of Lowry et al (19). Levels of immunoglobulins ( $\mathrm{Ig}$ ) G, A and M in CSF were estimated by laser nephelometry. The control group for analysis of CSF consisted of 12 males and 9 females who ranged in age from 21 to 71 years (average 41.9) and who had no evidence of organic disorders of the nervous system.

\section{Assay for 2',3'-cyclic nucleotide 3'-phosphohydrolase (CNP) activity in CSF}

Immediately after sampling, an aliquot of CSF was centrifuged at $1,500 \mathrm{rpm}$ and the supernatant was stored at $-80^{\circ} \mathrm{C}$. The CNP activity was estimated by the NADPcycling method as described elsewhere (20). Briefly, $50 \mu \mathrm{l}$ of CSF, to which Triton X-100 had been added to a final concentration of $1 \%$, were incubated for 2.5 hours at $25^{\circ} \mathrm{C}$ with $50 \mu \mathrm{l}$ of a solution that consisted of $0.4 \mathrm{M}$ 2[N-Morpholino]ethanesulfonic acid, $\mathrm{pH} 6.0 ; 30 \mathrm{mM}$ $\mathrm{MgCl}_{2} ; 1.0 \mathrm{mM}$ EDTA; $1.5 \mathrm{mM}$ glucose-6-phosphate dehydrogenese (Sigma, St. Louis, MO, USA); 0.03\% bovine serum albumin; and $2.0 \mathrm{mM} 2^{\prime}, 3^{\prime}$-cyclic NADP (Sigma) as substrate. The reaction was stopped by adding $1.0 \mathrm{ml}$ of $0.05 \mathrm{M}$ bicarbonate buffer, $\mathrm{pH} 10.6$, and the fluorescence of the NADPH generated in the reaction mixture was determined in a fluorometer (FP-550A; Nihon Bunkou, Tokyo, Japan) by reference to an NADP standard. Duplicated samples were assayed and heatinactivated CSF was used as a blank. The CNP activity was expressed as $\mathrm{nmol} / \mathrm{h} / \mathrm{ml} \mathrm{CSF}$. In this assay, the CNP activity was $2.70 \pm 0.32 \mu \mathrm{mol} / \mathrm{h} / \mathrm{mg}$-protein (mean $\pm \mathrm{SE}$ ) in the mouse sciatic nerve homogenate (three ICR mice, male, 8 weeks old).

\section{Results}

\section{Prodrome}

Early symptoms followed by facial paralysis were seen in 124 out of the 164 patients, as summarized in Table 1. About one half of the patients had ipsilateral otalgia and retroauricular pain, and/or occipital headache and nuchal stiffness. Symptoms suggestive of upper respiratory tract infection were not infrequent $(19.5 \%)$. In most cases, these symptoms had preceded the onset of facial paralysis by $2-10$ days.

\section{Routine laboratory findings (Table 2)}

According to the data obtained from the reference group, ESR of more than $20 \mathrm{~mm} / \mathrm{h}$, a white blood cell count of more than $8,000 \mathrm{cells} / \mu \mathrm{l}$, a CRP level of more than $0.4 \mathrm{mg} / \mathrm{dl}$, and a $\mathrm{CH}$ titer of more than $1: 32$ were

Table 1. Prodromes Observed in 124 Out of 168 Patients with Bell's Palsy

\begin{tabular}{lcc}
\hline Symptoms & $\begin{array}{c}\text { No. of } \\
\text { cases (\%) }\end{array}$ & $\begin{array}{c}\text { Preceding interval } \\
\text { days (mean) }\end{array}$ \\
\hline Otalgia, retroauricular pain & $43(26.2)$ & $1-19(4.1)$ \\
Headache, nuchal stiffness & $42(25.6)$ & $1-15(2.8)$ \\
Fever, sore throat, rhinorrhea & $32(19.5)$ & $1-21(5.8)$ \\
Nausea & $4(2.4)$ & $2-7(4.0)$ \\
Diarrhea & $3(1.8)$ & $5,7,15(9.0)$ \\
\hline
\end{tabular}

Table 2. Results of Routine Laboratory Tests in Patients with Bell's Palsy

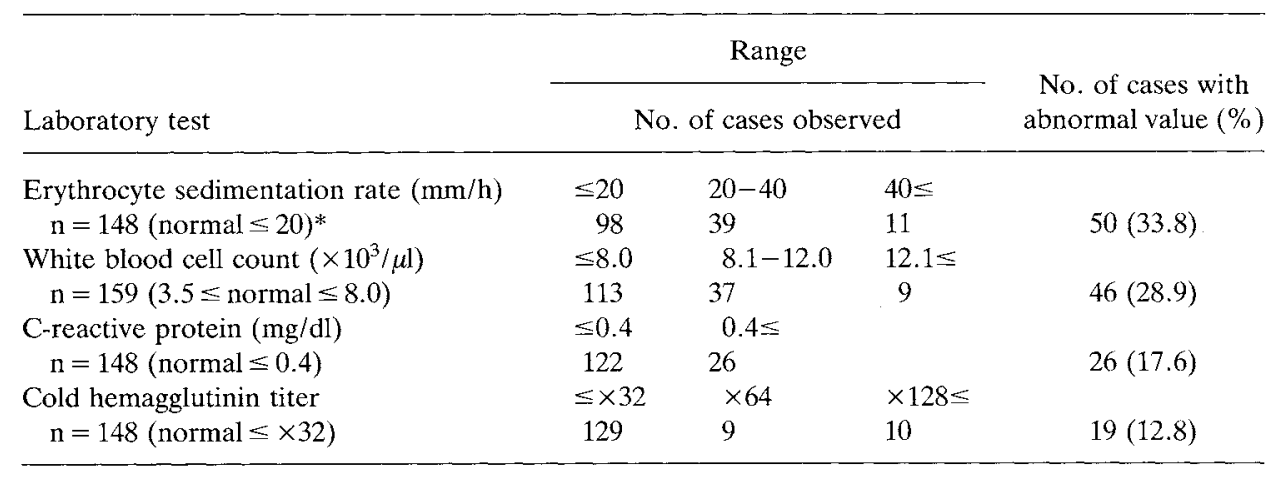

* Normal value was determined according to the data obtained from 76 healthy subjects. 


\section{Honda et al}

considered as positive findings. ESR was elevated in 50 $(34 \%)$ of 148 patients. Leukocytosis was found in 46 $(29 \%)$ of 159 patients. Serum CRP was positive in 26 $(18 \%)$ of 148 patients. Thus, at least one-third of the patients had increased ESR, leukocytosis, and/or elevated CRP, which indicated the presence of an inflammatory reaction. In addition, $19(13 \%)$ of 148 patients had elevated $\mathrm{CH}$ titers. Nine patients showed significant changes in $\mathrm{CH}$ titers, but none of them had antibodies against Mycoplasma pneumoniae.

\section{Virus antibody titers}

Of the 148 patients with Bell's palsy, $127(86 \%)$ had $\mathrm{CF}$ antibodies against HSV, and six (4\%) had CF antibodies against VZV at the time of the first visit (Fig. 1,
Table 3). Antibodies against mumps and Coxsackie A9 viruses were positive in $21(18 \%)$ and $31(26 \%)$ of 119 patients, respectively. Of the 115 samples of patients' serum examined, $93(81 \%)$ contained $\mathrm{IgG}$ antibodies against EBV (Table 3).

On subsequent examination, 2-5 weeks after the first sampling, four of 112 patients showed three- or fourfold changes in titers of HSV antibodies and one of 86 patients had a four-fold change in the titer of mumps virus antibodies, whereas titers of antibodies against VZV, Coxsackie A9 virus and EBV remained unchanged in all cases examined.

\section{CSF findings}

Figure 2 shows the results of the examinations of CSF

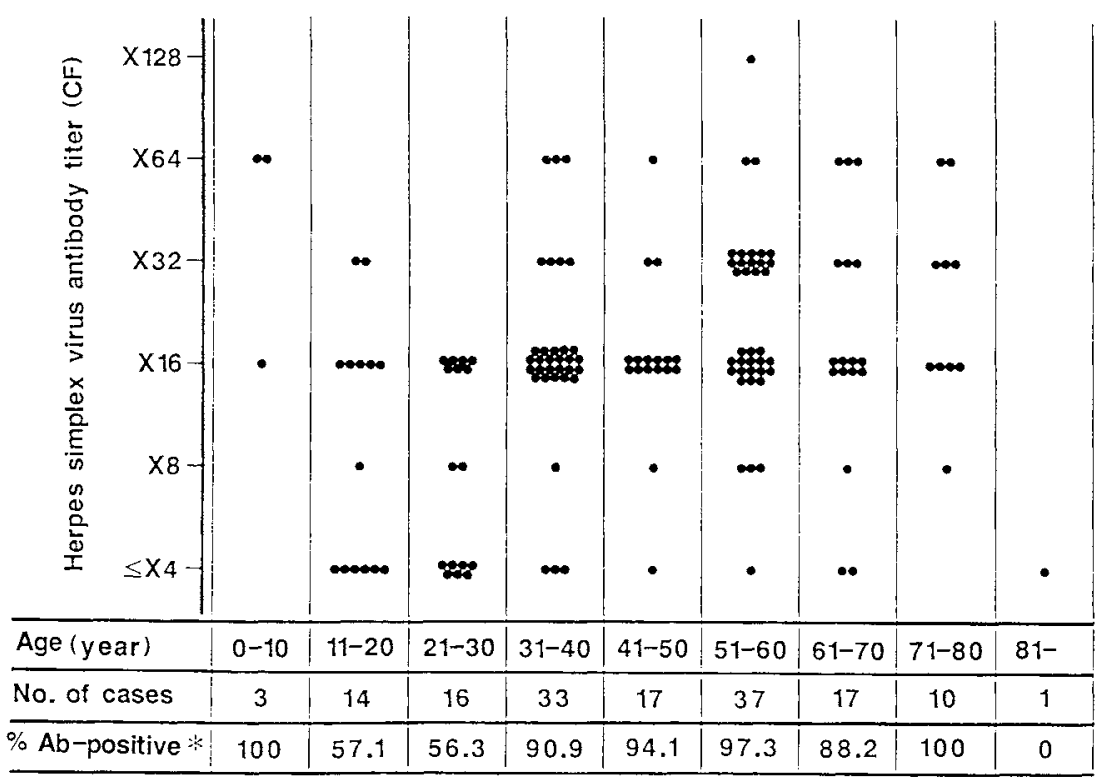

Fig. 1. Titer of antibodies against herpes simplex virus in the serum from 148 patients with Bell's palsy at the time of the first visit.

* Percentage of antibody-positive (titers of greater than 1:4) cases in cach age group.

Table 3. Virus-specific Antibody Titer in the Serum from Patients with Bell's Palsy

\begin{tabular}{|c|c|c|c|c|c|c|}
\hline Antibody titer $(C F) \#$ & $\leq \times 4$ & $\times 8$ & $\times 16$ & $\times 32$ & $\times 64$ & $\times 128 \leq$ \\
\hline $\begin{array}{l}\text { Herpes simplex virus } \\
\mathrm{n}=148\end{array}$ & $21^{*}$ & 10 & 75 & 28 & 13 & 1 \\
\hline $\begin{array}{l}\text { Varicella zoster virus } \\
\mathrm{n}=148\end{array}$ & 142 & 3 & 3 & 0 & 0 & 0 \\
\hline $\begin{array}{l}\text { Mumps virus } \\
\quad \mathrm{n}=119\end{array}$ & 98 & 7 & 11 & 3 & 0 & 0 \\
\hline $\begin{array}{l}\text { Coxsackie A9 virus } \\
\mathbf{n}=119\end{array}$ & 88 & 8 & 19 & 3 & 1 & 0 \\
\hline VCA-IgG antibody titer (IF)@ & $\leq \times 40$ & $\times 80$ & $\times 160$ & $\times 320$ & $\times 640$ & $\times 1280 \leq$ \\
\hline $\begin{array}{l}\text { Epstein-Barr virus } \\
\mathrm{n}=115\end{array}$ & 22 & 31 & 36 & 15 & 11 & 0 \\
\hline
\end{tabular}

* Number of cases observed. Serum samples were obtained from the patients at the time of the first visit. \# Titer of complement-fixing antibodies. @ Titer of IgG antibodies against virus capsid antigen assayed by an indirect immunofluorescence method. 


\section{Demyelination in Bell's Palsy}

from 91 patients with Bell's palsy. From the data for the 21 controls (reported in Table 4), the mean +2 SD values of various parameters were as follows: cell count, 10 cells $/ \mu \mathrm{l}$; total protein, $37.6 \mathrm{mg} / \mathrm{dl} ; \operatorname{IgG}, 3.4 \mathrm{mg} / \mathrm{dl}$; $\mathrm{IgG} \%$ (the amount of $\mathrm{IgG}$ as a percentage of the total protein), $12.0 \% ; \operatorname{IgA}$ and $\operatorname{IgM},<1.0 \mathrm{mg} / \mathrm{dl}$. In this study we employed the value of the mean $+2 \mathrm{SD}$ for the controls as the upper limit of normal. Of 91 patients, nine $(10 \%)$ had CSF pleocytosis (more than ten cells $/ \mu \mathrm{l}$ ), mostly of mononuclear cells, and 30 patients $(33 \%)$ had elevated protein levels of greater than $37.6 \mathrm{mg} / \mathrm{dl}$. Among the cases with an increase in CSF protein, pleocytosis
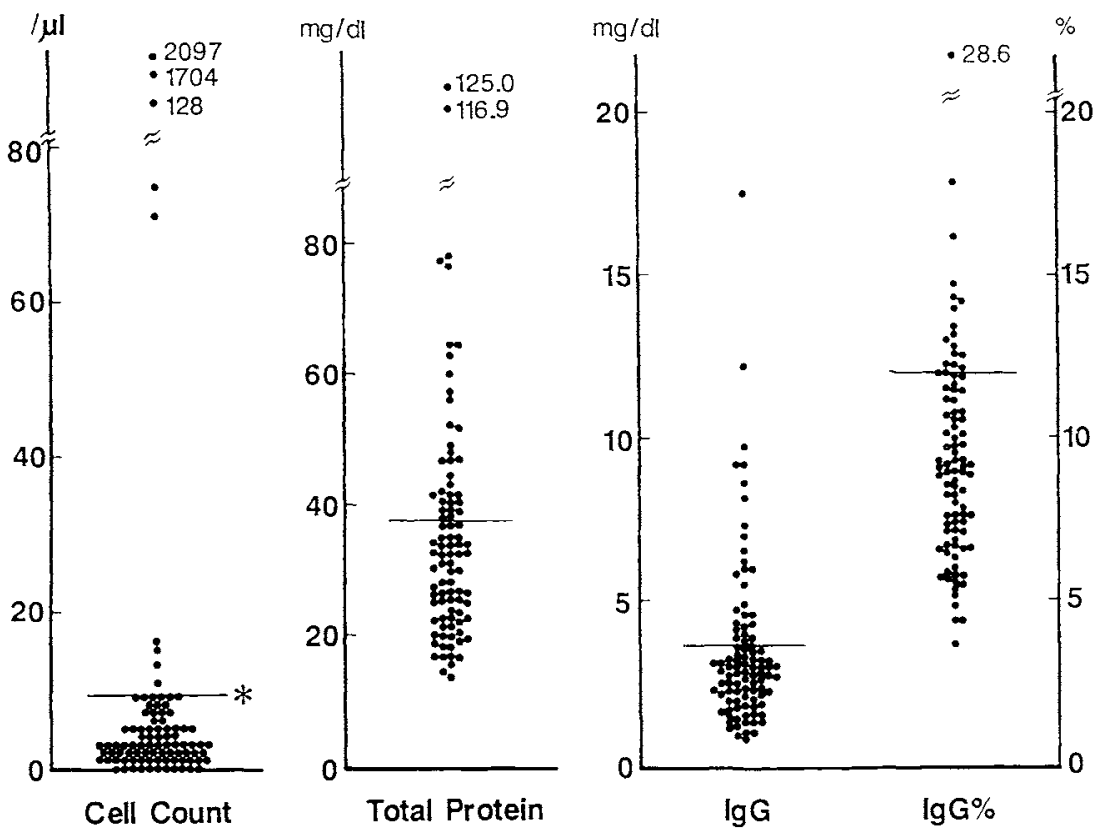

Fig. 2. Cerebrospinal fluid (CSF) findings in 91 patients with Bell's palsy. Samples of CSF were collected at the time of the first visit or within seven days of the onset of facial paralysis.

* Bar indicates the value of the mean +2 SD in 21 control subjects who had no evidence of organic disorders of the nervous system.

Table 4. Relationship between Titer of Serum HSV Antibodies and CSF Findings

\begin{tabular}{|c|c|c|c|c|c|c|c|}
\hline & \multirow[b]{2}{*}{$\begin{array}{l}\text { No. of } \\
\text { cases }\end{array}$} & \multirow[b]{2}{*}{$\begin{array}{c}\text { Age } \\
\text { (years) }\end{array}$} & \multicolumn{5}{|c|}{ CSF findings } \\
\hline & & & $\begin{array}{l}\text { cell count } \\
(/ \mu \mathrm{l})\end{array}$ & $\begin{array}{l}\text { total protein } \\
\qquad(\mathrm{mg} / \mathrm{d} l)\end{array}$ & $\begin{array}{c}\operatorname{IgG} \\
(\mathrm{mg} / \mathrm{dl})\end{array}$ & $\operatorname{IgG} \%$ & $\begin{array}{l}\text { CNP activity } \\
\text { (nmol/h/ml) }\end{array}$ \\
\hline Controls & 21 & $\begin{aligned} & 41.9 \\
\pm & 16.2 \#\end{aligned}$ & $\begin{array}{r}3.1 \\
\pm 2.9\end{array}$ & $\begin{array}{r}24.8 \\
\pm 6.4\end{array}$ & $\begin{array}{r}2.0 \\
\pm 0.7\end{array}$ & $\begin{array}{r}8.0 \\
\pm 2.0\end{array}$ & $\begin{array}{r}13.2 \\
\pm 1.3\end{array}$ \\
\hline Patients & 91 & $\begin{array}{r}45.5 \\
\pm 17.6\end{array}$ & $\begin{aligned} & 47.8(9) \mathrm{a} \\
\pm & 29.2\end{aligned}$ & $\begin{aligned} & 36.1(30) \mathrm{b} \\
\pm & 19.1^{* *}\end{aligned}$ & $\begin{aligned} & 3.5(28) \mathrm{b} \\
\pm & 2.6^{* *}\end{aligned}$ & $\begin{aligned} & 9.4(15) \mathrm{b} \\
\pm & 3.5\end{aligned}$ & $\begin{array}{l}15.5(29) \mathrm{b} \\
\pm 3.8^{* *}\end{array}$ \\
\hline \multicolumn{8}{|c|}{$\begin{array}{l}\text { HSV antibody } \\
\text { titer (CF) }\end{array}$} \\
\hline$\leq \times 4$ & 17 & $\begin{array}{r}32.2 \\
\pm 17.7\end{array}$ & $\begin{aligned} & 3.4(0) \\
\pm & 2.6\end{aligned}$ & $\begin{aligned} & 31.1(4) \\
\pm & 13.3\end{aligned}$ & $\begin{aligned} & 2.7(4) \\
\pm & 1.4\end{aligned}$ & $\begin{aligned} & 8.4(0) \\
\pm & 2.2\end{aligned}$ & $\begin{array}{l}13.8(3) \\
\pm 1.9\end{array}$ \\
\hline$\times 8, \times 16$ & 53 & $\begin{array}{r}48.0 \\
\pm 15.3\end{array}$ & $\begin{aligned} & 75.7(6) \\
\pm & 50.4\end{aligned}$ & $\begin{array}{r}37.5(19) \\
\pm 18.9^{* * *}\end{array}$ & $\begin{aligned} & 3.7(18) \\
\pm & 2.4^{* *}\end{aligned}$ & $\begin{aligned} & 9.7(10) \\
+ & 3.4\end{aligned}$ & $\begin{array}{l}15.6(19) \\
\pm 3.1^{* * * *}\end{array}$ \\
\hline$\times 32, \times 64 \leq$ & 21 & $\begin{array}{r}49.9 \\
\pm 18.6\end{array}$ & $\begin{array}{l}15.6(3) \\
\pm 7.3\end{array}$ & $\begin{aligned} & 36.3(7) \\
\pm & 23.4^{*}\end{aligned}$ & $\begin{aligned} & 3.7(6) \\
\pm & 3.6^{*}\end{aligned}$ & $\begin{aligned} & 9.7(5) \\
\pm & 3.2^{*}\end{aligned}$ & $\begin{array}{l}16.6(7) \\
\pm 5.8^{* *}\end{array}$ \\
\hline
\end{tabular}

\# Values are expressed as the mean \pm SD.

a Numeral in the parenthesis is the number of patients showing the cell count of more than 10 cells $/ \mu \mathrm{l}$.

$b$ Numeral in the parenthesis is the number of patients showing the value of greater than the mean $+2 \mathrm{SD}$ for controls.

$*$,**, *** Statistical significance (Student's t-test) at $\mathrm{p}<0.05, \mathrm{p}<0.01, \mathrm{p}<0.001$ as compared with controls, respectively. 
was present in only four cases. A total of 28 patients $(31 \%)$ had elevated levels of IgG of greater than $3.4 \mathrm{mg} /$ $\mathrm{dl}$ and 15 patients $(16 \%)$ had an increase in $\mathrm{IgG} \%$ of more than $12 \%$. Eight patients had elevated levels of IgA which ranged from 1.0 to $2.3 \mathrm{mg} / \mathrm{dl}$, but the $\operatorname{IgM}$ content was below $1 \mathrm{mg} / \mathrm{dl}$ in all the cases examined. An increase in both total protein and IgG content in the CSF was observed in $23(25 \%)$ out of the 91 patients.

The time course of changes in CSF protein content was examined in 14 patients who consented to repeat lumbar punctures. In five patients the levels of protein in the CSF tended to increase for 3-6 weeks after the onset of the disease and three patients showed a prolonged elevation of protein levels, with values consistently above $50 \mathrm{mg} / \mathrm{dl}$. By contrast, the marked pleocytosis (more than $100 \mathrm{cells} / \mu \mathrm{l}$ ) that had been observed in three patients at the first sampling was replaced by a nomral cell count within $2-6$ weeks.

\section{CNP activity in CSF}

We estimated the CNP activity in the CSF from 91

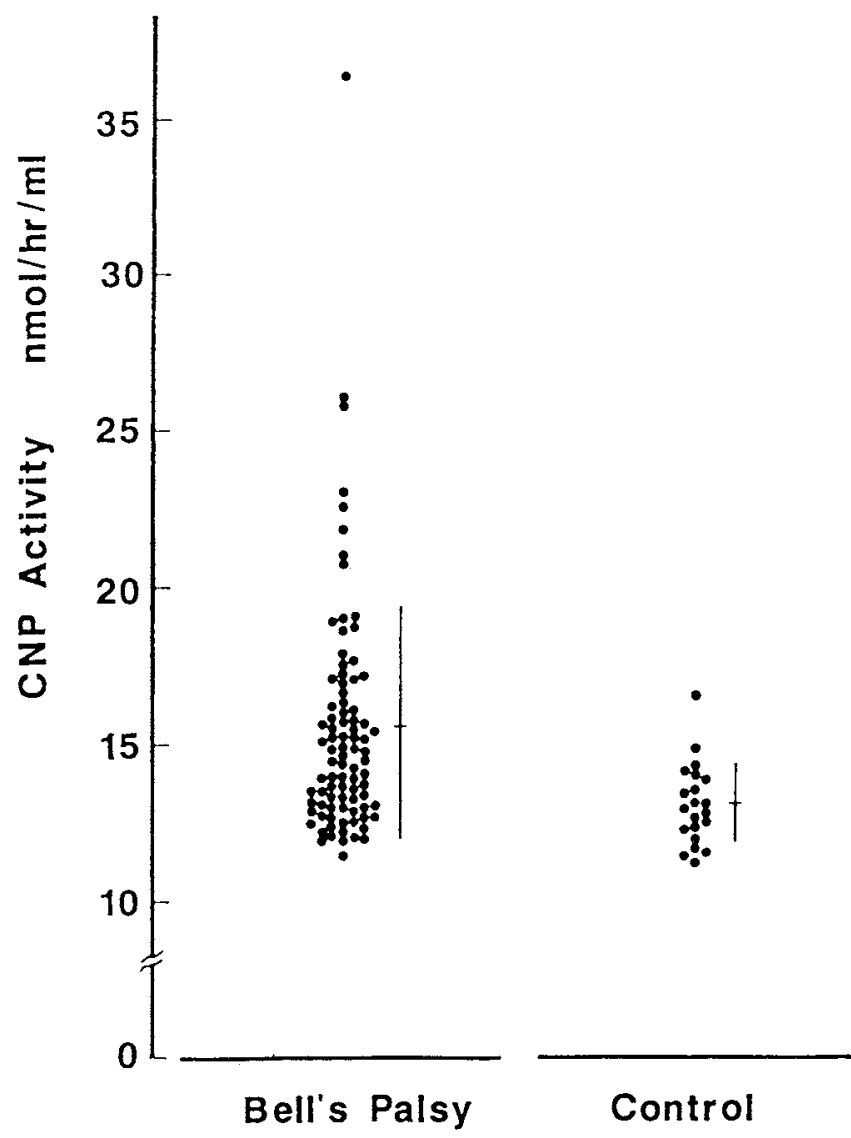

Fig. 3. 2', 3'-cyclic nucleotide $3^{\prime}$-phosphohydrolase (CNP) activity in the CSF. CNP activity was estimated by NADP cycling method (20). CSF samples were obtained from 91 patients with Bell's palsy and 21 control subjects. The enzyme activity was $15.5 \pm 3.8 \mathrm{nmol} / \mathrm{h} / \mathrm{ml}$ (mean $\pm \mathrm{SD}$ ) in the patient group, and was significantly higher than that $(13.2 \pm 1.3 \mathrm{nmol} / \mathrm{h} / \mathrm{ml})$ in the control (Student's t-test, $\mathrm{p}<0.01$ ) patients with Bell's palsy and 21 control subjects. The results are presented in Fig. 3. There was a significant elevation in CNP activity in the patient group $(15.5 \pm 3.8$ $\mathrm{nmol} / \mathrm{h} / \mathrm{ml})$ as compared with that in the control $(13.2 \pm$ $1.3 \mathrm{nmol} / \mathrm{h} / \mathrm{ml}$ ) (Student's $t$-test, $\mathrm{p}<0.01$ ). At the first sampling, 29 patients $(32 \%)$ had elevated enzyme activities of greater than the value of the mean +2 SD for the controls $(15.8 \mathrm{nmol} / \mathrm{h} / \mathrm{ml})$. The time course of changes in CNP activity was examined in ten patients at $2-10$ weeks after the onset of facial paralysis. As shown in Fig. 4, seven showed a decrease and three showed a slight increase in the CNP activity.

The CNP activity was statistically correlated with both the total protein $(\mathrm{r}=0.353, \mathrm{p}<0.01)$ and levels of $\operatorname{IgG}(r=0.259, \mathrm{p}<0.05)$ in the CSF. An analysis of the correlation between the titer of HSV antibodies and CNP activity revealed that the patients who were positive for the antibodies (titers of greater than 1:4) had a higher CNP activity than those who were negative (Table 4). The four patients who showed significant changes with time in the titer of HSV antibodies also had elevated $\mathrm{CNP}$ activity, whereas a patient with a recent mumps virus infection, as indicated by changes in antibody titers, did not. Furthermore, the patients who were positive for HSV antibodies tended to have a high incidence of abnormal CSF findings (Table 4). By contrast, there was no significant relationship between the serum antibody

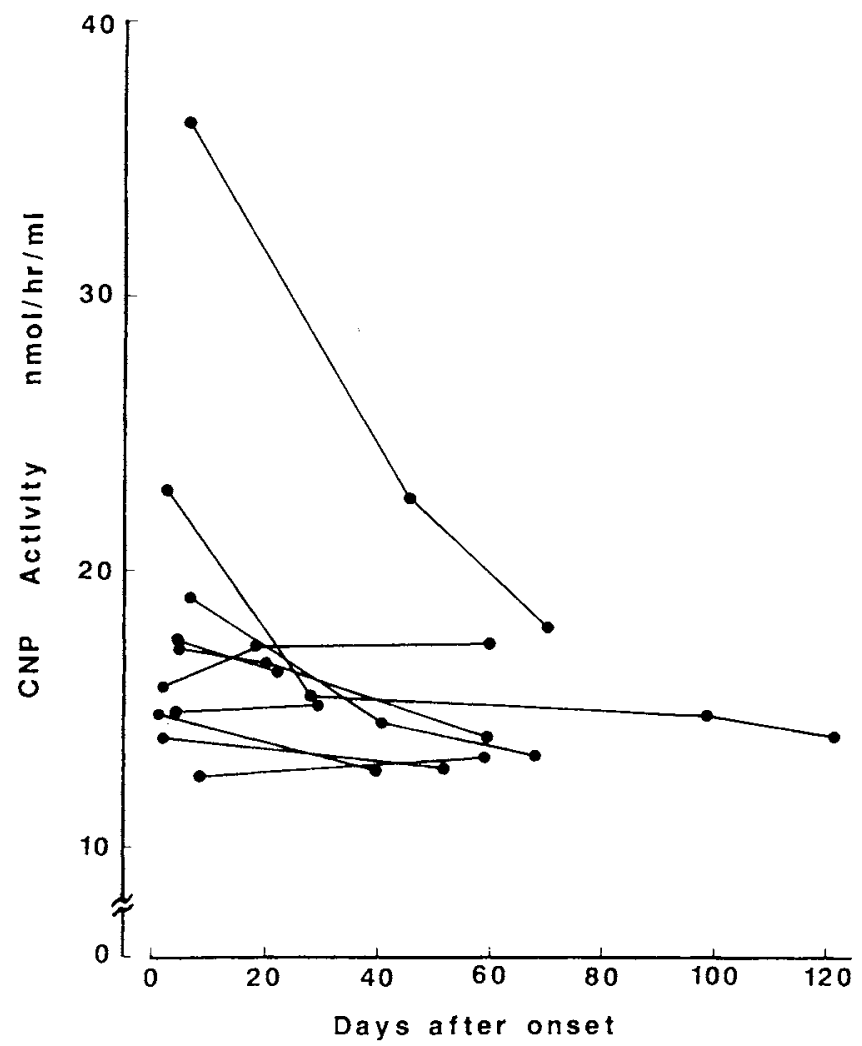

Fig. 4. The time course of changes in CNP activity in the CSF from ten patients with Bell's palsy. 
titers against VZV, EBV, mumps virus, Coxsackie A9 virus and the $\mathrm{CSF}$ findings, including CNP activity.

\section{Discussion}

The present study demonstrated that Bell's palsy is frequently accompanied by an inflammatory reaction, abnormal CSF findings and elevated CNP activity in the CSF. Furthermore, the results of virus serology suggest that these pathologic changes may be associated with HSV infection or reactivation.

It was reported that pain accompanied paralysis in about $60 \%$ of cases of Bell's palsy (5). In the present study, $42(25.6 \%)$ of 168 patients had an aching pain that was not only localized at the auricular site but extended over the occipital area as well, and some of these patients $(5 / 42)$ had spinal fluid pleocytosis, which indicated the presence of inflammation of nervous structures. Furthermore, as previously reported (21), symptoms suggestive of upper respiratory tract infection were often followed by facial paralysis, and nearly half of the patients had hematological and/or serological evidence of an inflammatory reaction. Thus, it seems likely that inflammatory changes are frequently involved in the early phases of facial paralysis.

There have been few reports of CSF findings associated with Bell's palsy $(6,22)$. The present study demonstrated that a relatively high incidence of CSF abnormalities accompanied facial paralysis, such as increased levels of total protein ( 30 cases) and occasional pleocytosis ( 9 cases) in 91 patients with Bell's palsy. The cases that presented with an elevated total protein level were apparently more frequent than those with pleocytosis, and this picture of CSF abnormalities can be defined as "albumino-cytological dissociation". In addition, about one-third of the patients had elevated levels of $\operatorname{IgG}, \operatorname{IgA}$ or IgG\% in the CSF. These CSF findings indicate that intrathecal inflammatory or immunological changes occur in a large fraction of patients with Bell's palsy.

It is of interest that these CSF findings are quite similar to those observed in cases of acute inflammatory demyelinating polyneuropathy (23). In this regard, some investigators $(24,25)$ have suggested that acute peripheral facial palsy is part of a polyneuropathy. Abramsky et al (26) demonstrated a similarity between Bell's palsy and Guillain-Barré syndrome (GBS) with regard to lymphocyte sensitization to the same peripheral nerve basic protein, and suggested that cell-mediated autoimmune mechanisms may be an important factor in the pathogenesis of the paralysis. In GBS an etiological relation with a specific viral infection has not yet been established. However, it has been postulated that autoimmune neurological disorders might be triggered by previous viral infections (27), and in fact, several neurotropic viruses have on occasion been isolated from patients with GBS (28). These observations suggest a final pathway common to both disorders in which inflammatory demyelination leads to nerve injury, although the basic etiology could be different.

We attempted to examine whether a demyelinating process occurs during the development of facial paralysis. The significant elevation of CNP activity suggests that, at least in some cases of Bell's palsy, the breakdown of myelin does occur, since CNP has been found as a myelin-associated enzyme and elevated CNP activity is thought to be a marker of demyelination $(17,29)$. Although CNP is known to be highly active in the central nervous system and the activity is much lower in the peripheral nerve (30), this enzyme has been reported to be present in the peripheral myelin fragment (31). Using the same method as employed herein, Raes et al (32) found elevated activity of this enzyme in the CSF of patients with radiculopathy and peripheral neuropathy.

From the changes in virus-specific antibody titers, facial paralysis appeared to be associated with a recent viral infection in only a few patients, namely, infection with HSV in four cases and with mumps virus in one case. These findings suggest the rare association of a primary viral infection with the onset of facial paralysis. However, the results of virus serology showed a high frequency of antibodies against HSV and EBV $(86 \%$ and $81 \%$, respectively). This observation may simply reflect a high prevalence of these viruses in the general population $(33,34)$. However, several lines of evidence suggest that Bell's palsy may be caused by infection or reactivation of viruses, in particular $\operatorname{HSV}(7,12)$, and it has been demonstrated that, in cases of herpes virus infection, the antibody titers only occasionally fluctuate before, during or after the recrudescence of the infection $(35,36)$. Therefore, even if a direct connection between the antibodies and the clinical condition remains to be established, it seems possible that high titers of HSV antibodies found in the serum of patients with Bell's palsy are compatible with recurrent or reactivated infection with HSV. Our observation of an association between the antibodies against HSV, but not against EBV, and CSF abnormalities including elevated CNP activity in patients with Bell's palsy, supports this hypothesis.

In this study, several patients had underlying conditions, such as diabetes mellitus, hypertension, and pregnancy. Participation of these conditions, either directly or indirectly, in the disorder of the facial nerve cannot be ruled out (37). Even the increase in CNP activity might occur as a result of nonspecific insults to the facial nerve that induce the breakdown of myelin, such as compression ischemia within the facial canal adjacent to the CSF pathway. However, the inflammatory reactions and accompanying spinal fluid abnormalities, including the elevated CNP activity, together with a high incidence of HSV antibodies suggest that, in at least some patients with Bell's palsy, HSV-as- 


\section{Honda et al}

sociated demyelination may play a pathogenetic role in the development of facial nerve paralysis.

\section{References}

1) Taverner D. Bell's palsy: a clinical and electromyographic study. Brain 78: 209, 1955.

2) Zülch KJ. "Idiopathic" facial paralysis. in: Handbook of Clinical Neurology, vol 8, Diseases of Nerves, Part II, Vinken PJ, Bruyn GW, Eds. North-Holland Publishing, Amsterdam, 1970, p. 241.

3) Proctor B, Corgill DA, Proud G. The pathology of Bell's palsy. Trans Am Acad Ophthalmol Otol 82: 70, 1976.

4) Djupesland G, Berdal P, Johannssen TA, Degré M, Stien R, Skrede $S$. The role of viral infection in acute peripheral facial palsy. Acta Otolaryngol 79: 221, 1975.

5) Adour KK, Byl FM, Hilsinger RL, Kahn ZM, Sheldon MI. The true nature of Bell's palsy: analysis of 1,000 consecutive patients. Laryngoscope 88: 787, 1978.

6) Djupesland G, Berdal P, Johannssen TA, Degré M, Stien R, Skrede S. Viral infection as a cause of acute periphcral facial palsy. Arch Otolaryngol 102: 221, 1976.

7) Adour KK, Bell DN, Hilsinger RL. Herpes simplex virus in idiopathic facial paralysis (Bell's palsy). JAMA 233: 527, 1975.

8) McCormick DP. Herpes-simplex virus as cause of Bell's palsy. Lancet i: 937, 1972 .

9) Brackman DE. Bell's palsy. Incidence, ctiology and results of medical treatment. Otolaryngol Clin North Am 7: 357, 1974.

10) Beardwell A. Facial palsy duc to the mumps virus. Br J Clin Pract 23: $37,1966$.

11) Grose C, Feorino PM, Dye LA, Rand J. Bell's palsy and infectious mononucleosis. Lancet ii: 231, 1973.

12) Davis LE. Experimental virus infections of the facial nerve and geniculate ganglion. Ann Neurol 9: 120, 1981.

13) Kristensson K, Svennerholm B, Lycke E. Herpes simplex virusinduced demyelination: effects of reinfection and challenge with neuroantigens. J Neurol Sci 60: 247, 1983.

14) Townsend JJ, Collins PK. Peripheral ncrvous system demyelination with herpes simplex virus. J Neuropathol Exp Neurol 45: 419, 1986.

15) Devriese PP. Facial paralysis in cephalic herpes zoster. Ann Otol Rhinol Laryngol 77: 1101, 1968.

16) Engler $\mathrm{CW}$, Missal $\mathrm{SC}$, Involvement of the cranial nerves in poliomyelitis. Trans Am Acad Ophthalmol Otolaryngol 59: 732, 1955.

17) Banik NL, Mauldin LB, Hogan EL. Activity of 2',3'-cyclic nucleotide $3^{\prime}$-phosphohydrolase in human cerebrospinal fluid. Ann Neurol 5: 539, 1979.

18) Tomita H, Hayakawa W, Hondo R. Varicella-zoster virus in idiopathic facial palsy. Arch Otolaryngol 95: 364, 1972.

19) Lowry $\mathrm{OH}$, Rosebrough NJ, Farr AL, Randall RJ. Protein measurement with the Folin-phenol reagent. J Biol Chem 193:
$265,1951$.

20) Weissbarth S, Marker HS, Lehrer GM, Schneider S, Bornstein MB. A sensitive fluorometric assay for $2^{\prime}, 3^{\prime}$-cyclic nucleotide $3^{\prime}-$ phosphohydrolase. J Neurochem 35: 503, 1980.

21) Hydén D, Sandstedt P, Ödkvist LM. Prognosis in Bell's palsy based on symptoms, signs and laboratory data. Acta Oto-laryngol 93: $407,1982$.

22) Park HW, Watkins AL. Facial paralyses: analyses of 500 cases. Arch Phys Med 30: 749, 1949.

23) Link H. Immunoglobulin abnotmalities in the Guillain-Barré syndrome. J Neurol Sci 18: 11, 1973.

24) Djupesland G, Degré M, Stien R, Skrede S. Acute peripheral facial palsy: Part of a cranial polyneuropathy? Arch Otolarygol 103: 641, 1977.

25) Sandstedt P, Hydén D, Ödkvist L. Bell's palsy: part of a polyneuropathy? Acta Ncurol Scand 64: 66, 1981.

26) Abramsky O, Webb C, Teitelbaum D, Arnon R. Cellular immune response to peripheral nerve basic protein in idiopathic facial paralysis (Bell's palsy). J Neurol Sci 26: 13, 1975.

27) Clatch RJ, Lipton HL, Miller SD. Characterization of Theiler's murine encephalomyclitis virus (TEMV) specific delayed-type hypersensitivity response in TEMV-induced demyelinating disease: correlation with clinical signs. J Immunol 136: 920, 1986.

28) Sigwald $\mathbf{J}$, Nouailhat $\mathbf{F}$. The Guillain-Barré syndrome. in: Handbook of Clinical Neurology, vol 7, Diseases of Nerves, Part I, Vinken PJ, Bruyn GW, Eds. North-Holland Publishing, Amsterdam, 1970 , p. 495.

29) Sprinkle TJ, Mckhann GM. Activity of $2^{\prime}, 3^{\prime}$-cyclic nucleotide $3^{\prime}$-phosphodiesterase in cerebrospinal fluid of patients with demyelinating disorders. Neurosci Lett 7: 203, 1978.

30) Uyemura K, Tobari C, Hiramo S, Tsukada Y. Comparative studies on the myelin protein of bovine peripheral nerve and spinal cord. J Neurochem 19: 2607, 1972.

31) Kurihara T, Nussbaum JL, Mandel P. $2^{\prime}, 3^{\prime}$-cyclic nucleotide $3^{\prime}$-phosphohydrolase in brains of mutapt mice with deficient myelination. J Neurochem 17: 993, 1970.

32) Raes I, Weissbarth S, Maker HS, Lehrer GM. 2', 3'-cyclic nuclcotide $3^{\prime}$-phosphodiesterasc in cerebrospinal fluid. Neurology 31: 1361, 1981.

33) Hadar T, Tovi F, Sidi J, Sarov B, Sarov I. Specific IgG and IgA antibodies to herpes simplex virus and varicella zoster virus in acute peripheral facial palsy patients. J Med Virol 12: 237, 1983.

34) Hondo R. A seroepidemiological study of herpes simplex virus. Jpn J Med Sci Biol 27: 205, 1974.

35) Cesario TC, Poland JD, Wulff H, Chin TDY, Wenner HA. Six years experience with herpes simplex virus in children's home. Am J Epidemiol 90: 416, 1969.

36) Nahmias AJ, Roizman B. Infection with herpes-simplex viruses 1 and 2. N Engl J Med 289: 719, 1973.

37) Karnes WE. Discases of the seventh cranial nerve. in: Peripheral Neuropathy, Dyck PJ, Thomas PK, Lambert EH, Bunge R, Eds. WB Saunders Company, Philadelphia, 1984, p. 1266. 